DOE/NV/10845--15

DE93 003157

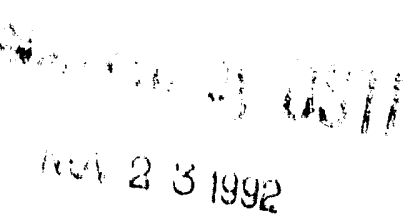

\title{
ESTIMATES OF POTENTIAL RADIONUGLUDE MIGRATION AT THE BULLION SITE
}

\author{
by \\ T.H. Brikowski
}

April 1992

Publication \#45097 
This report was prepared as an account of work sponsored by the United States Government. Neither the United States nor the United States Deparment of Energy, nor any of their employees, makes any warranty, express or implied, or assumes any legal liability or responsibility for the accuracy, completeness or usefulness of any information, apparatus, product or process disclosed, or represents that its use would not infringe privately owned rights. Reference herein to any specific commercial project. process, or service by trade name, mark, manufacturer, or otherwise, does not necessarily constitute or imply its endorsement, recommendation, or favoring by the United States Government or any agency thereof. The views and opinions of authors expressed herein do not necessarily state or reflect those of the United States Government or any agency thereof.

This report has been reproduced directly from the best available copy.

Available to DOE and DOE contractors from the Office of Scientific and Technical Information, P.O. Box 62, Oak Ridge, TN 37831; prices available from (615) 576-8401.

Available to the public from the National Technical Information Service, U.S. Department of Commerce, 5285 Port Royal Rd., Springfield, VA 22161. 


\title{
ESTIMATES OF POTENTIAL RADIONUCLIDE MIGRATION AT THE BULLION SITE
}

\author{
by \\ Tom H. Brikowski \\ Water Resources Center \\ Desert Research Institute \\ University and Community College System of Nevada \\ Reno, Nevada
}

Publication \#45097

Prepared for

U.S. Department of Energy

Nevada Field Office

Las Vegas, Nevada

under Contract DE-AC08-90NV10845

April 1992 


\begin{abstract}
The Bullion site in Area 20 of the Nevada Test Site has been selected for an intensive study of the hydrologic consequences of underground testing, including subsequent radionuclide migration. The bulk of the chimney and cavity lie in zeolitized tuffs of low hydraulic conductivity, while the base of the cavity may extend downward into more conductive rhyolite flows. A mathematical analog to the Bullion setting is used here to estimate expected radionuclide migration rates and concentrations. Because of a lack of hydrologic data at the site, two contrasting scenarios are considered. The first is downward-transport, in which downward hydraulic gradients flush chimney contents into the conductive underlying units, enhancing migration. The other is upward-transport, in which upward gradients tend to drive chimney contents into the low-conductivity zeolitized tuffs, discouraging migration. In the downward-transport scenario, radionuclide travel times and concentrations are predicted to be similar to those encountered at Cheshire, requiring approximately 10 years to reach a proposed well $300 \mathrm{~m}$ downgradient. The upward transport scenario yields predicted travel times on the order of 2,000 years to the downgradient well. The most likely scenario is a combination of these results, with vertical movement playing a limited role. Radionuclides injected directly into the rhyolites should migrate laterally very quickly, with travel times as in the downward-transport scenario. Those in the zeolitized tuff-walled portion of the chimney should migrate extremely slowly, as in the upward-transport scenario.
\end{abstract}




\section{CONTENTS}

$\begin{array}{lll}\text { ABSTRACT } & \text { ii }\end{array}$

FIGURES iv

TABLES $\quad v$

PREFACE 1

INTRODUCTION 2

SETTING 2

Hydraulic Conductivity $\quad 7$

Hydraulic Potential 8

Porosity

Distribution of Dissolved Radionuclides

ANAL.YTIC SOLUTIONS $\quad 10$

$\begin{array}{ll}\text { PROCEDURE } & 14\end{array}$

$\begin{array}{ll}\text { Validation } & 18\end{array}$

$\begin{array}{ll}\text { Predictions } & 19\end{array}$

Uncertainty 20

CONCLUSIONS

$\begin{array}{lr}\text { REFERENCES } & 25\end{array}$ 


\section{FIGURES}

1. Location of the Bullion Site (U-2)bd) and Neighboring Wells.

2. Cross Section Showing Stratigraphic and Structural Setting of the Bullion Emplacement Well.

3. Geologic Map of the Bullion (U-20bd) Site.

4. Cross Section Showing Location and Stratigraphic Setting of Approximate Cavity and Chimney at Bullion.

5. Variation in Water Levels During Drilling at U-20bd.

6. Tritium Concentrations vs. Depth at the Faultless Site.

7. Geometry of Flow System Treated by Analytic Solution.

8. Downward-Transport Scenario for Groundwater Movement and Radionuclide Migration at Bullion.

9. Upward-Transport Scenario for Groundwater Movement and Radionuclide Migration at Bullion.

10. Sensitivity of Flux Estimates for Upper Aquifer, Upward-Transport Scenario.

11. Sensitivity of Chimney Contribution in Upper Aquifer, UpwardTransport Scenario.

12. Sensitivity of Flux Estimates for Lower Aquifer, Downward-Transport Scenario.

13. Sensitivity of Chimney Contribution in Lower Aquifer, DownwardTransport Scenario. 


\section{TABLES}

$\begin{array}{ll}\text { 1. List of Symbols. } & 13\end{array}$

2. Inputs: Parameter Values Used in Flux Computations. 17

3. Results: Chimney Contribution and Total Flux for Bullion Scenarios. 18 


\section{PREFACE}

This report was originally prepared in the Fall of 1990 to support planned drilling of a downgradient hydrologic monitoring hole at the Bullion site. Rough predictions of anticipated travel times for contaminants were needed to determine the optimum monitoring location. Subsequent loss of access to a postshot hole to be used for cavity monitoring (U2)bd-PSaa) made the Bullion site less desirable for downgradient monitoring. As a result, the report was not completed at that time.

Since the initial preparation of this report, the mathematical solutions have been refined and their application reported on in several papers (Brikowski, 1992a; Brikowski, 1992b; Brikowski, 1991a). The present report contains information useful to any further investigations at the Bullion site and, therefore, it has been released for publication. The interested reader is referred to Brikowski (1991b) in particular for estimates of tritium plumes at this site. 


\section{INTRODUCTION}

Estimates of likely concentrations and rates of migration of radionuclides in groundwater at the Bullion site are developed in this report. The Bullion device was detonated in 1990 approximately $50 \mathrm{~m}$ below the water table, and the site has been proposed for a "cradle to grave" study of radionuclide migration related to underground testing. Predictions of radionuclide migration are needed for the planning of future observations and experiments at this site; however, making accurate predictions is difficult because of lack of site-specific hydrologic information. For this reason, the relative effects of various factors are emphasized here rather than precise estimates of travel time and concentrations.

Stratigraphic and geometric information (e.g., cavity location, etc.) at the site are relatively well established. Relatively' unknown are the distribution of hydraulic conductivity and hydraulic head. Best estimates for these paramiters based on the collective opinion of Nevada Test Site (NTS) geologists, and on limited data available nearby, suggest that the geologic units forming most of the cavity and chimney walls are significantly less permeable than underlying units. A small, upward-directed head gradient is probable, which should serve to contain most of the dissolved radionuclides in the less conductive rocks. Those radionuclides emplaced directly in the underlying permeable unit should migrate rapidly away from the site. Two scenarios are considered here based on direction of water movement in the chimney. One is "downward-transport," in which a downward-directed gradient encourages migration of chimney contents into the underlying conductive units, and the other is "upward-transport," in which a small upward gradient and low conductivity of chimney wall rocks limits radionuclide migration. The likelihood of either scenario is unknown, although the upward-transport scenario is favored by the conventional wisdom regarding Pahute Mesa hydrology.

Hydrologic predictions can be made using numerical techniques or analytic (exact mathematical) solutions. In the case of a poorly characterized setting such as the Bullion site, analytic solutions are preferred since results can be expressed as functions of one or more of the unknown parameters. A disadvantage of this approach is that a greatly simplified view of the system is often required. Numerical models demand little simplification, but require specific values for all parameters, and are of limited use when input parameters are highly uncertain. Analytic solutions are used below to estimate radionuclide travel times and concentrations expected in a proposed downgradient well at the Bullion site.

\section{SETTING}

The Bullion test was detonated June 13, 1990, beneath Pahute Mesa in Area 20) of the NTS (see Figure 1 for location). The device was emplaced $50 \mathrm{~m}$ below static water level at a depth of $674 \mathrm{~m}$ (see cross section, Figure 2; location of cross section given in Figure 3). This 

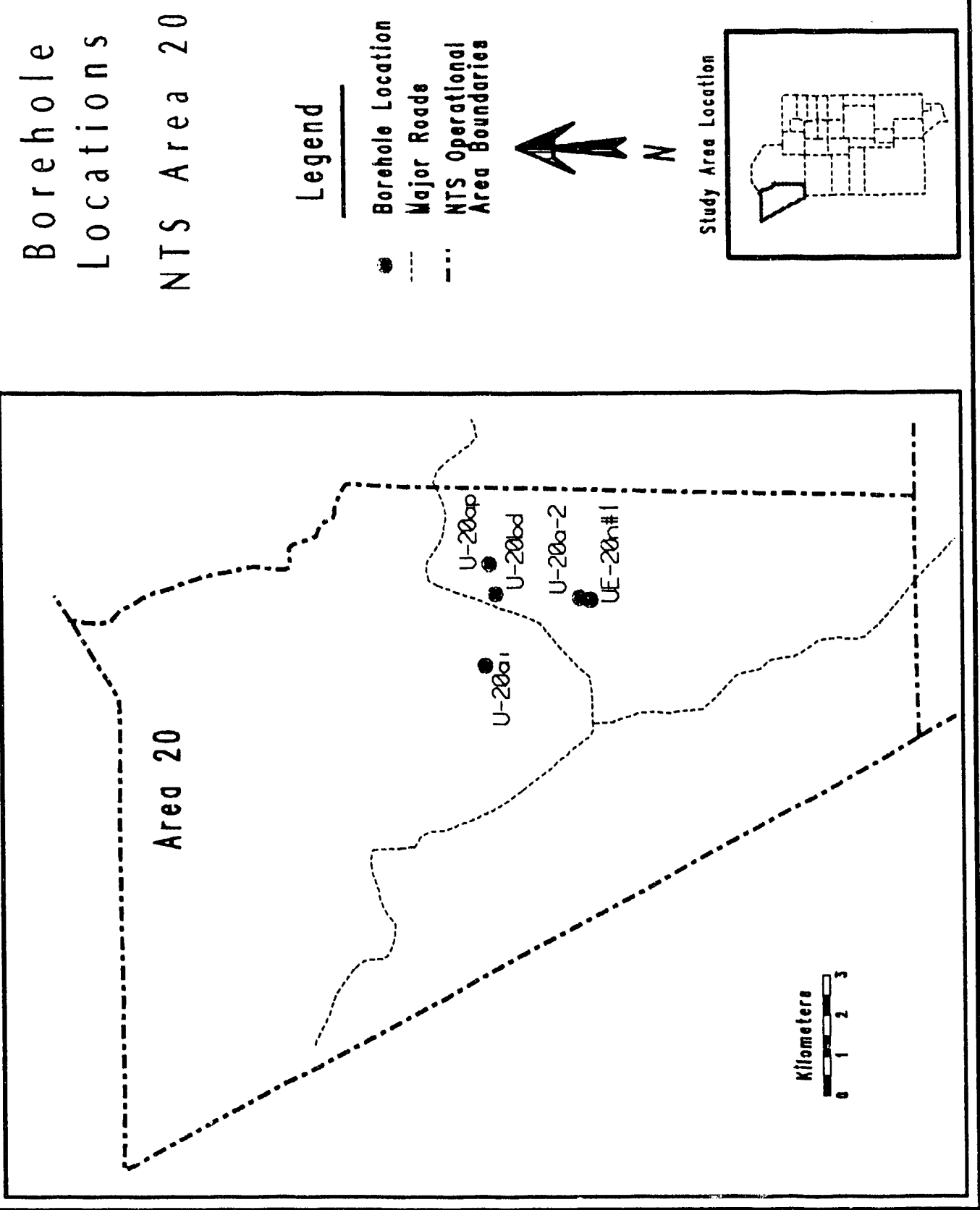

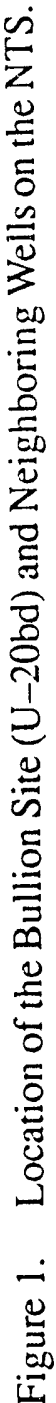




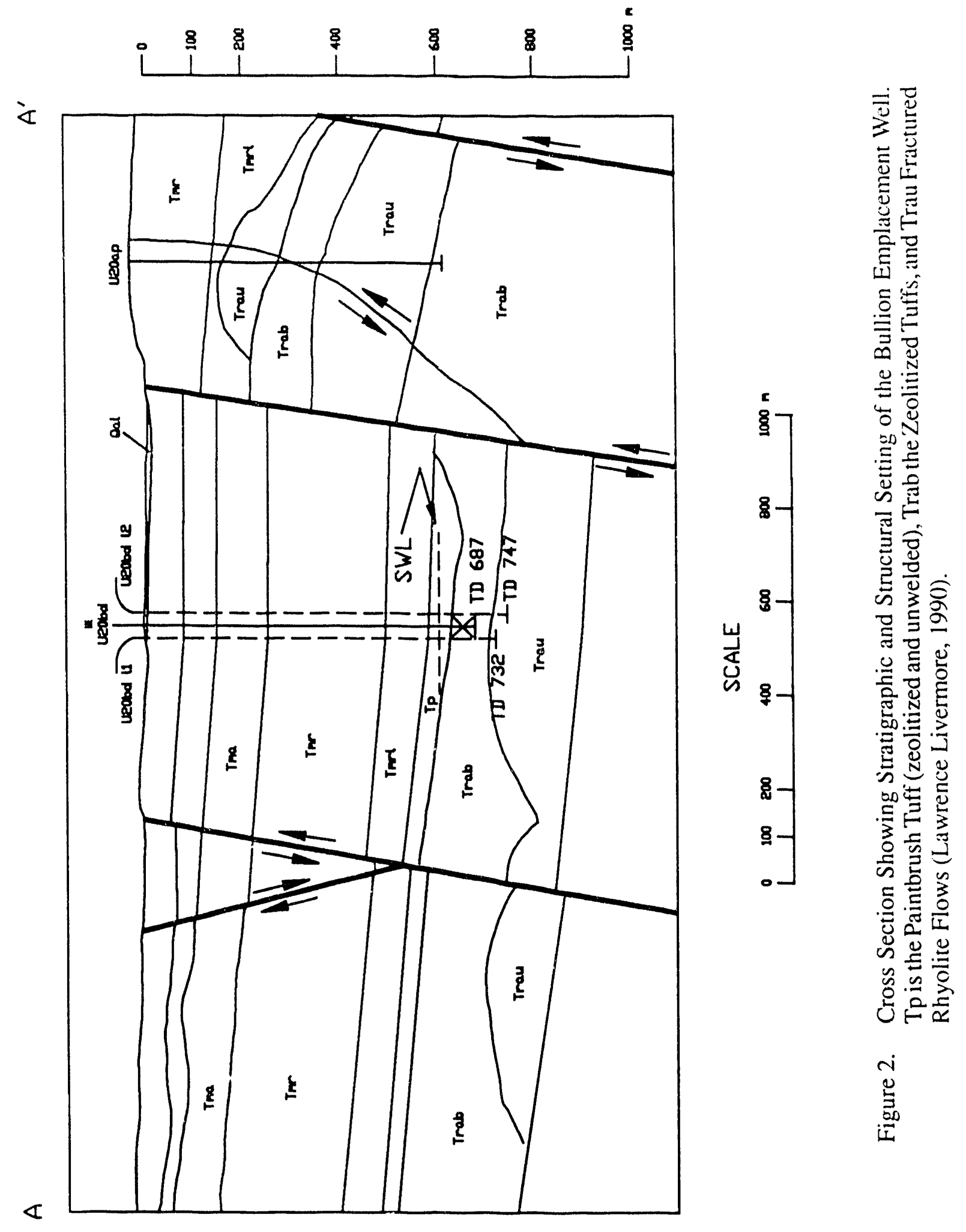




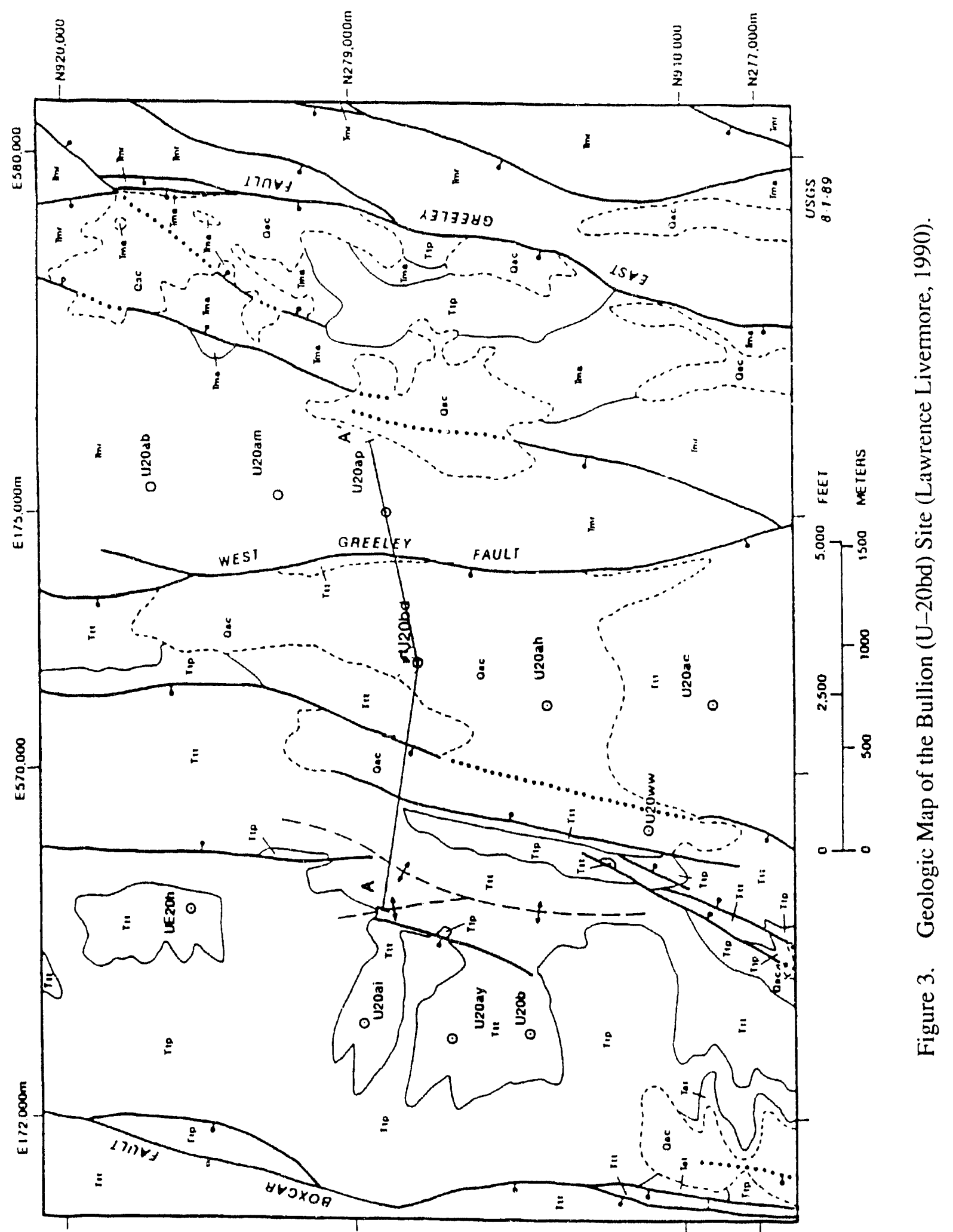


location is within the Undifferentiated Tuffs and Rhyolites of Area 20 (referred to as zeolitized tuffs in this report, Trab in Figure 2). Assuming a typical cavity radius of $60 \mathrm{~m}$, the cavity would extend upward into the Paintbrush Tuff ( $\mathrm{Tp}$ ), and the chimney into the Rainier Mesa Tuff (Tmr, Figure 4). Part of the cavity, as well as shot-generated fractures, would extend into the underlying lavas of Area 20 (referred to as rhyolite flows in this report, Trau in Figure 3).

Cavity radius can be estimated in another way. A "maximum credible radius" can be determined from the depth of burial (DOB) of the test using expressions in Glasstone and

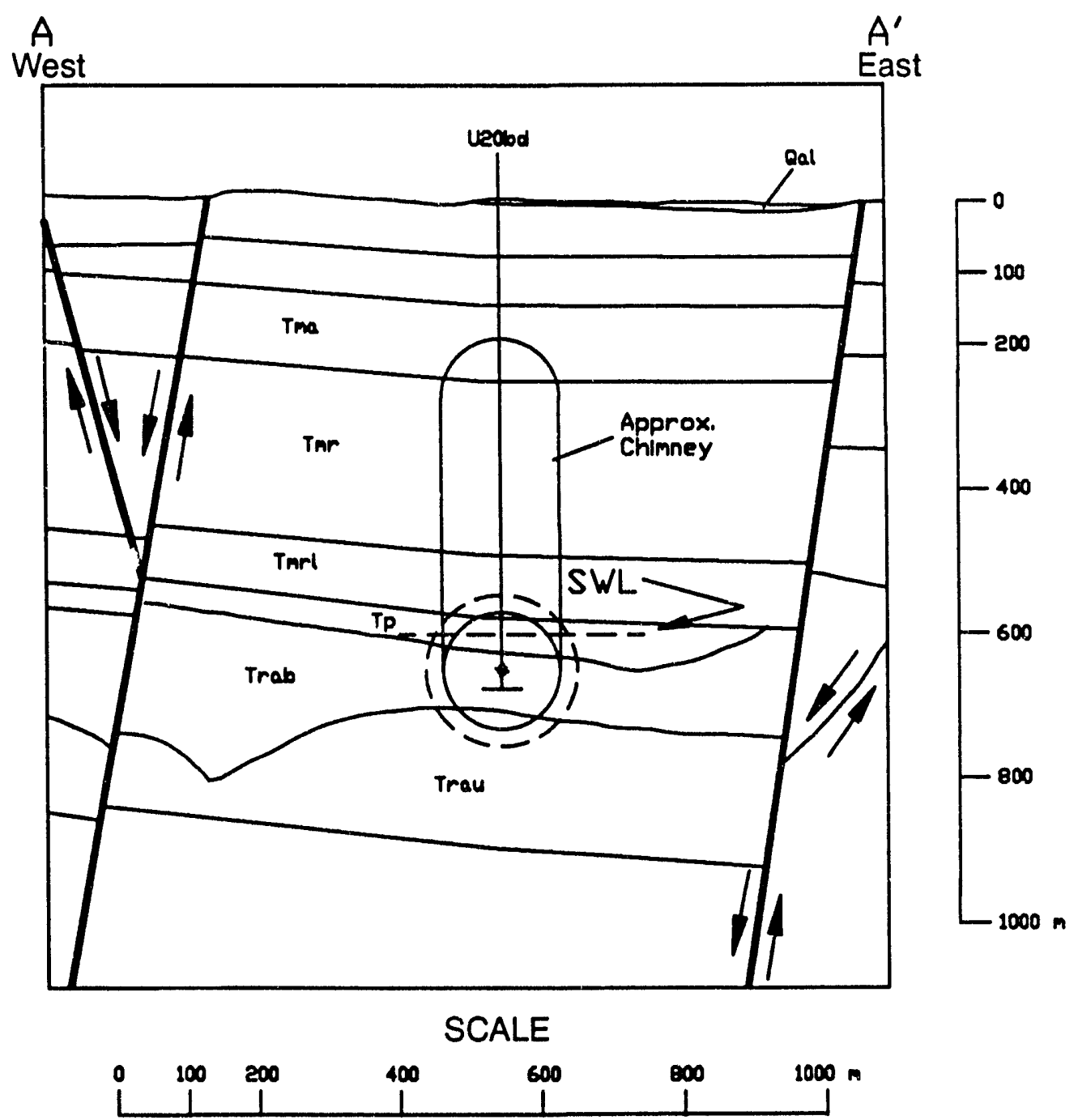

Figure 4. Cross Section Showing Location and Stratigraphic Setting of Approximate Cavity and Chimney at Bullion. Dashed circle is approximate extent of heavy fracturing. Geologic base from Site Characteristics Report. 
Dolan (1977). This radius is given by 0.0875 - DOB (see Brikowski, 1991b). The maximum credible cavity radius at the Bullion site is $59 \mathrm{~m}$.

Parameters needed for prediction of radionuclide migration include the hydrologic characteristics of the site (hydraulic conductivity, porosity, and head distributions), distribution of the initial radionuclide source, and nature of the thermal and pressure pulses from the test. Since all of these parameters have yet to be measured at the site, predictions must be made with "best guess" values. The data used in constraining these values are summarized below. Since the analytic solution used in making the predictions treats steady isothermal flow, only conductivity and head distributions need to be specified.

\section{Hydraulic Conductivity}

At the Bullion site, zeolitized tuffs comprise most of the walls of the chi : "cy and cavity. The Trab unit encountered in the emplacement well is described as 80 to 90 percent zeolitized (Lawrence Livermore National Laboratory, 1990). For this reason, it is expected to have a very low conductivity. A mean value for hydraulic conductivity from 34 core samples of zeolitized tuff from the NTS has been reported at $2 \times 10^{-3} \frac{\mathrm{m}}{\text { day }}$ (or $2.3 \times 10^{-8} \frac{\mathrm{m}}{\mathrm{scc}}$; Borg et al., 1976, p. 30). Most fractures in this unit are likely to be filled with zeolites as well and, therefore, values measured on recovered cores probably reflect the true bulk conductivity of the rock.

A relatively safe assumption is that the rhyolite flows are more conductive than the zeolitized tuffs at the Bullion site. The underlying rhyolite flow units (Trau) are generally highly fractured and quite conductive (Blankennagel and Weir, 1973). About $2.5 \mathrm{~km}$ southwest of Bullion at UE-20a\#2, some $650 \mathrm{~m}$ of this unit were encountered, with three principal permeable zones occurring, presumably related to the presence of conductive fractures (Drellack. 1987). Pumping tests of well UE-20a\#2 yielded a transmissivity of $3.11 \times 10^{-3} \frac{\mathrm{m}^{2}}{\mathrm{scc}}$ (reported as 18,000 ) $\frac{\mathrm{gal}}{\text { day } \mathrm{ft}}$; Blankennagel and Weir, 1973). For a pumped zone $742 \mathrm{~m}$ in height, this corresponds to a conductivity of $3.49 \times 10^{-6} \frac{\mathrm{m}}{\mathrm{scc}}\left(4.66 \times 10^{-6} \frac{\mathrm{m}}{\mathrm{sec}}\right.$ if Trau is considered to be the only flow unit). The mean value measured by Blankennagel and Weir (1973) for transmissivity of rhyolite flows on Pahute Mesa was $4.63 \times 10^{-3} \frac{\mathrm{m}^{2}}{\mathrm{scc}}$, with a range of $1.97 \times 10^{-4}$ to $2.01 \times 10^{-2} \frac{\mathrm{m}^{2}}{\mathrm{scc}}$ (Borg et al., 1976, p. 35).

Hydraulic conductivity of the overlying Paintbrush unit (Tp) is uncertain. This unit is described as 75 to 90 percent zeolite, with secondary silica visible in pores (Lawrence Livermore National Laboratory, 1990). Since the unaltered unit is generally composed of unwelded, airfall tuffs, it is likely to be relatively unfractured and have low conductivity even when fresh. 
Hydraulic conductivity within the chimney is unknown. The bulking properties of most Pahute Mesa units suggest conductivity will increase over that in the wall rocks. At the Faultless underground test site, the presence of a small layer of unwelded tuff. similar to the Paintbrush. appeared to significantly impede flow through the chimney (Thordarson, 1987). The conductivity of puddle glass may also be a factor, since it could isolate the base of the cavity from the surrounding rhyolite lavas. The hydrologic effect of this glass is entirely unknown.

\section{IIydraulic Potential}

The distribution of head in the vicinity of Bullion is not well known. Measurements of static water levels in nearby wells suggest that the regional (horizontal) head gradient is low. Between wells U-20a and U-20bd, a southwestward gradient of magnitude 0.018 is observed. Upward vertical gradients were observed in U-20)a, with magnitude 0.018 , between conductive zones in the rhyolite flow (Trau) unit and between the rhyolite flows and overlying zeolitized tuff (Trab) (Blankennagel and Weir, 1973). Throughout Area 20, upward vertical gradients are common.

In some cases, the variation of head with depth can be determined from water level variations observed during drilling; unfortunately, at U-20bd the introduction of drilling fluids may have strongly influenced water levels. Considered independently, water level records for the well U-20bd are indicative of decreasing head with depth (Figure 5). In particular, the period from 80 to 100 Julian days suggests water level equilibration at an elevation around $1,380 \mathrm{~m}$, with a well bottom elevation of $1,340 \mathrm{~m}$. After deepening the well, the standing water level decreased to $1,356 \mathrm{~m}$. Much of the fluid that reentered the well after blowing out appeared to be drilling fluid (McKinnis, personal comm.) and, therefore, the water level at 100 Julian days may represent substantially greater-than-equilibrium values. The low conductivity of the zeolitized tuffs should tend to keep drilling fluids in the vicinity of the well, allowing head to increase locally. The rhyolite flows are more likely to dissipate any drilling effects, and the low and constant standing water level after hole deepening may reflect the proximity of the rhyolite flows. A non-equilibrium interpretation of this data is supported by the fact that the observed water-level changes indicate an upward gradient of 0.45 , much larger than typical NTS values.

\section{Porosity}

An important factor in determining the infill time and dissipation of temperature and concentration anomalies is the porosity in the near-field environment. Total porosity of the stratigraphic units is well known for the preshot environment, and approximations for the postshot are possible. Lawrence Livermore (1990) gives average total porosities of 45 volume percent in the Tp and Trab. The porosity declines to 25 percent in the rhyolite flows. Effective, 


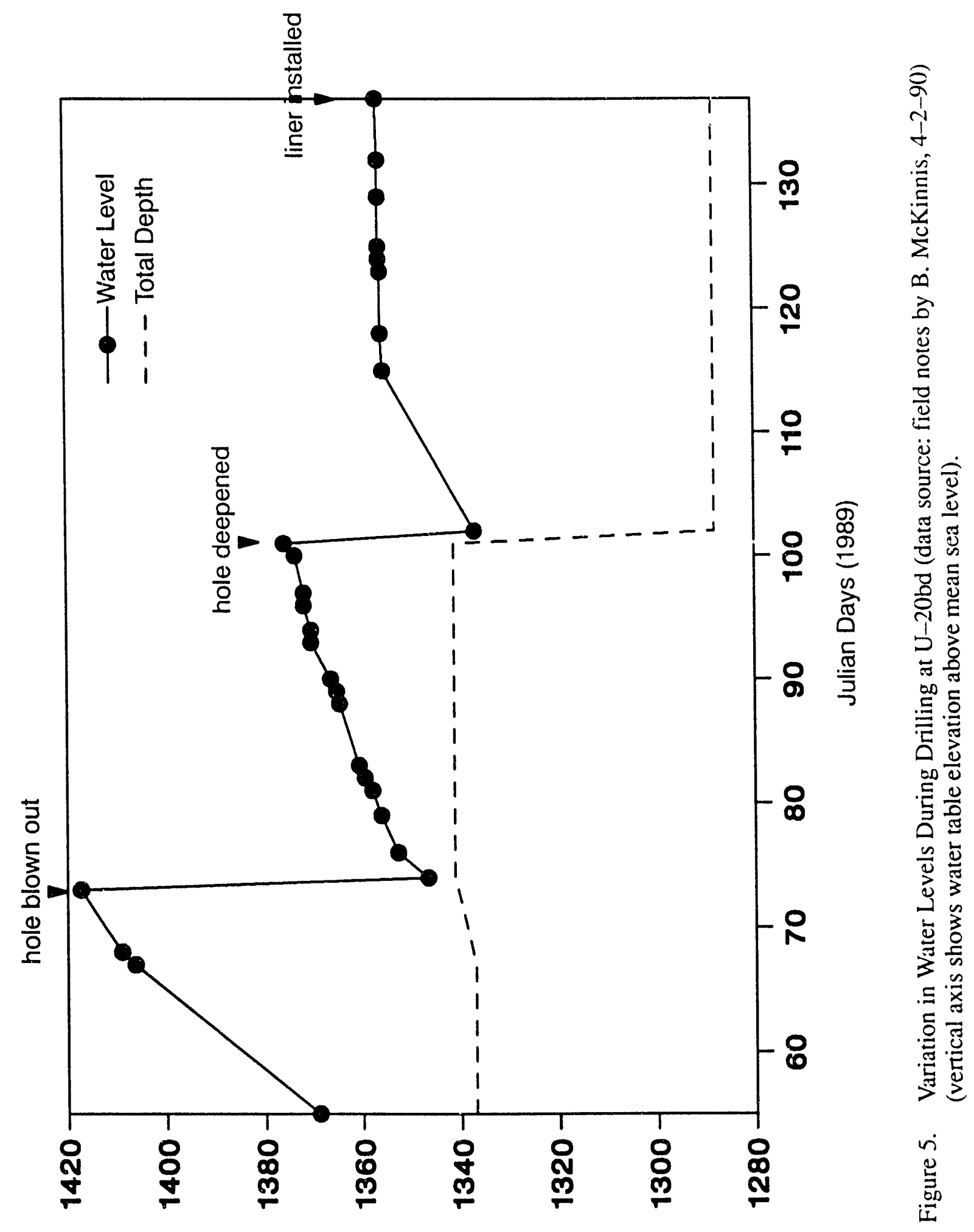

(ii) рәләך дәџем 
or flow porosity, will be considerably smaller. Estimates for the Yucca Flat area are 0.1 to 1 percent for zeolitized tuff (corresponding to the Paintbrush and Area 20) tuffs) (Garber, 1971). In the chimney rubble, effective porosity can increase by an order of magnitude, and Garber (1971) reports chimney effective porosities of 5 to 8 percent for zcolitized ash-flow tuff, and 1 to 3 percent for bedded tuff (analogous to the Tp unit). An estimated mean value of effective porosity in Pahute Mesa chimneys is 15 percent (Fenske, 1969).

\section{Distribution of Dissolved Radionuclides}

The Bullion chimney intersects two distinctly different hydrostratigraphic units and, therefore, radionuclides in the lower part of the chimney may have a different fate than those in the upper part. For this reason, the distribution of radionuclides in the chimney may be important in predicting observed concentrations away from the chimney.

Very little data are available on the distribution of radionuclides within cavities and chimneys. Thordarson (1987) provides some indication of the distribution of tritium with depth in the Faultless chimney (Figure 6). Conflicting trends are present in the Faultless data. Concentrations at any depth remained relatively constant with time while the chimney filled with water, although other time-series data suggest irregular periods of rising hot water or descending cold water, perhaps indicating sluggish convection in the chimney. Water appeared to perch within the chimney near a depth of $700 \mathrm{~m}$, the approximate location of the sharp jump in tritium concentrations (Figure 6).

In general, the Faultless chimney seemed to be characterized by downward movement of water during filling, implying filling from above. The Bullion chimney seems likely to fill from below since that is the location of the most conductive units. In such a case, radionuclides are likely to be more evenly distributed in the chimney than observed at Faultless. For the purposes of this study, concentrations at the base of the chimney will be assumed to equal values observed

at Cheshire seven months after detonation $\left(2.0 \frac{\mu \mathrm{Ci}}{\mathrm{ml}}\right)$, decreasing linearly to $\left(0.2 \frac{\mu \mathrm{Ci}}{\mathrm{ml}}\right.$ at the standing water level in the chimney (Erikson, 1990).

\section{ANALYTIC SOLUTIONS}

Given the above information, we seek constraints on the rate of travel, concentration, and total amount of tritium that may escape from the Bullion chimney. Analytic solutions describing groundwater flow through test chimneys can be used to provide some of these constraints (Brikowski, 1991a). This type of solution is particularly useful in cases where parameter values are poorly known because relative impacts of changes in parameter values are easily determined. The solutions used below describe only water movement and mixing in the geometry shown in 


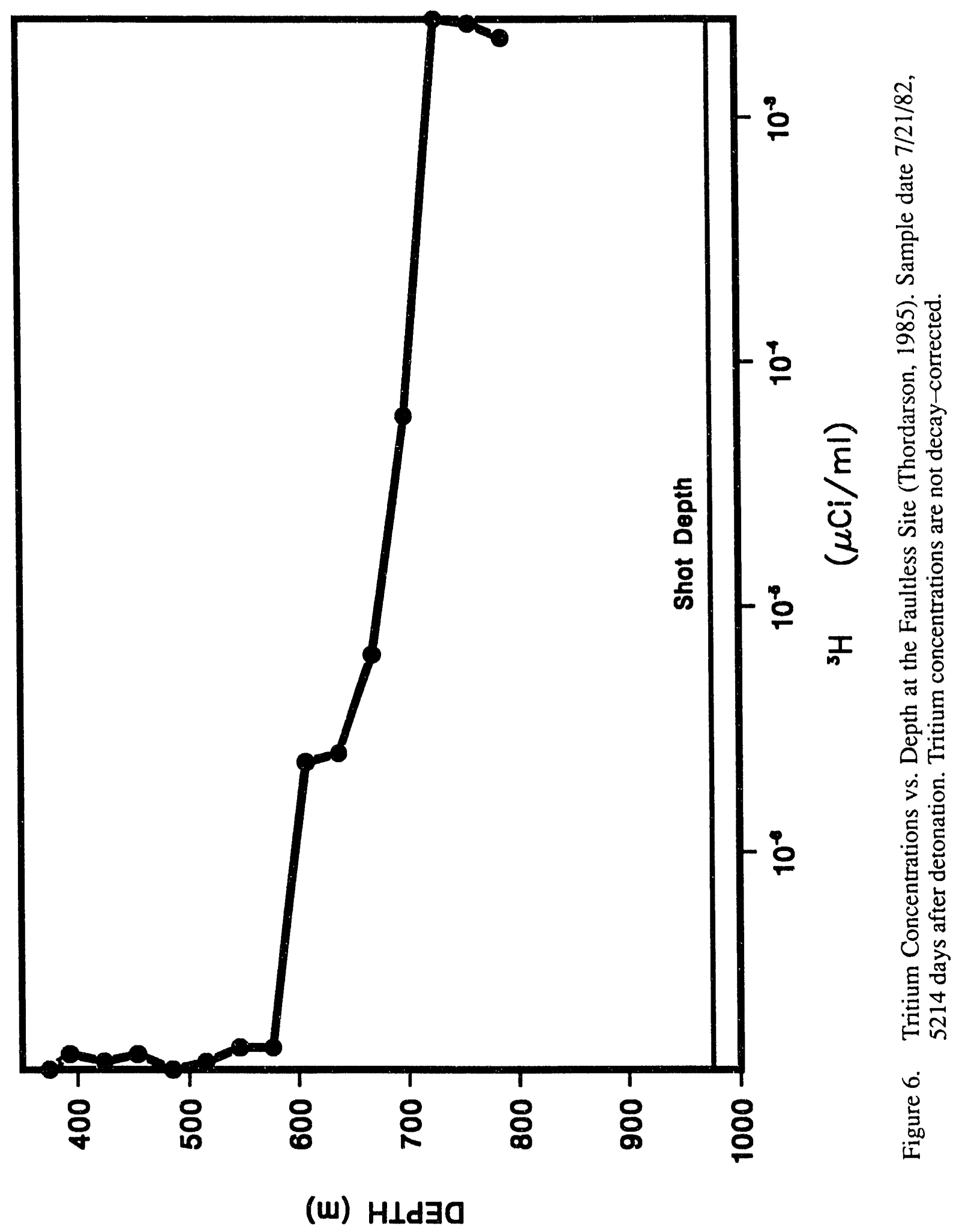


Figure 7, and do not explicitly treat transport processes. In addition, the solutions assume steady isothermal flow and, therefore, apply to the natural system only after the cavity has filled with groundwater and cooled to near-background temperatures. This geometry considers the chimney to be a permeable cylinder that connects two tabular aquifers.

Equations are presented below that express the total groundwater flux in the aquifers and the fraction of that water that has passed through the chimney. This fraction can be interpreted as the dilution expected as a result of mixing of warer that has flowed through the chimney with water that has flowed only through the aquifer. Such a dilution factor can be used to constrain expected radionuclide concentrations. Given assumptions about the thickness of the aquifers, the total flux can be used to estimate groundwater velocity and thereby constrain radionuclide travel times. The major influences on radionuclide migration at the Bullion site are expected to be conductivity of the zeolitized iuffs and the direction and magnitude of vertical hydraulic gradients. The analytic solutions include these parameters explicitly, and can be used to examine the impact of variability in the parameters on predictions of groundwater movement and radionuclide migration.

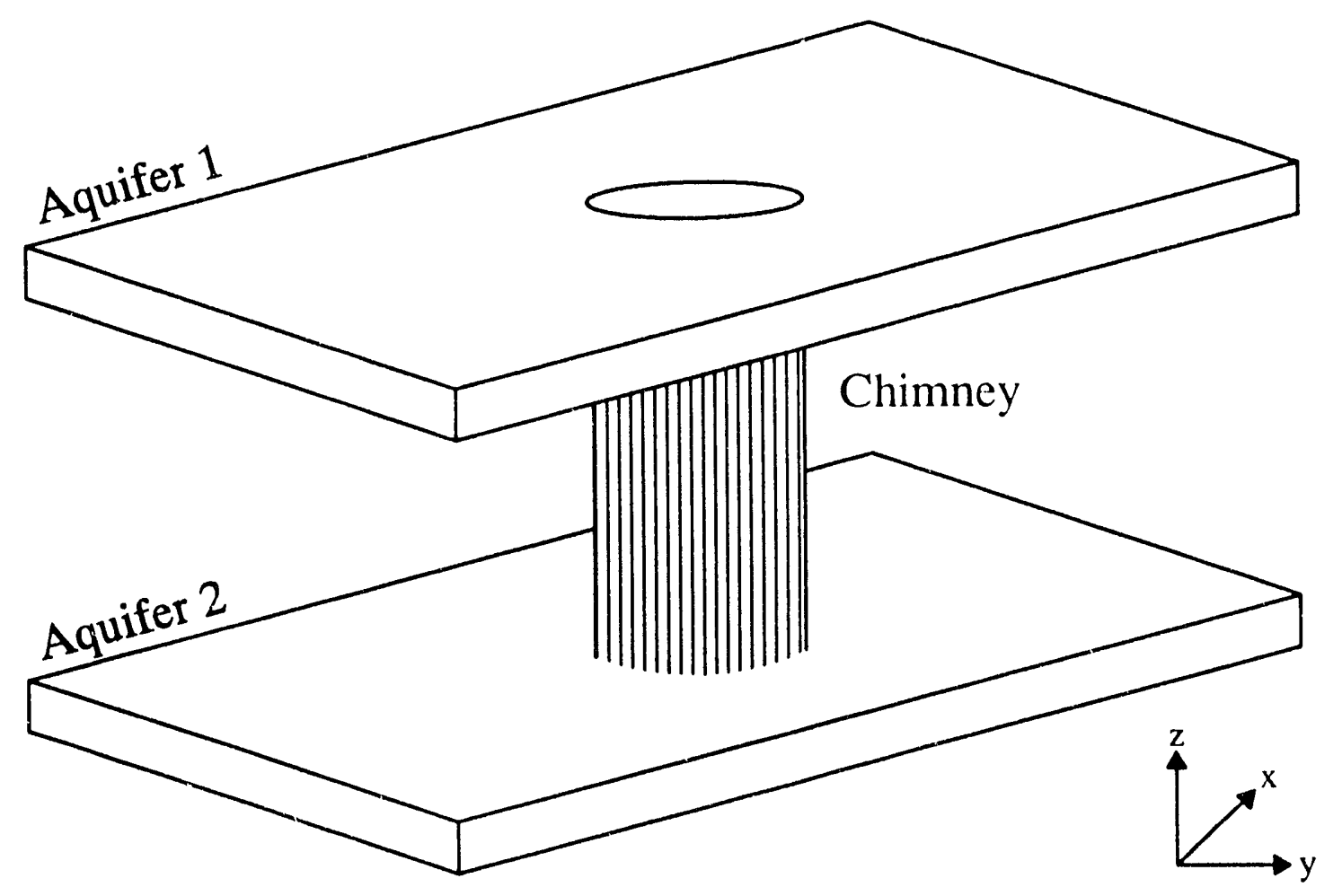

Figure 7. Geometry of Flow System Treated by Analytic Solution. 
The steady-state distribution of head and flux in this idealized geometry (Figure 7) has been described by Brikowski (1991a). Head in each of the aquifers is expressed as a function of position, and flux through the chimney $\mathrm{Q}_{c}$ as a function of head gradients and problem geometry. These solutions can be rearranged to obtain the ratio of chimney flux to total flux in the aquifer at any point downgradient from the chimney.

Given expressions for the head $h_{i}(x, y)$ at any point in each aquifer (Brikowski, 199la, p. 15), groundwater flux in the aquifer can be expressed as $Q_{i}=-T_{i} \nabla h_{i}$. The $x$-components of this flux at any point $(x, y)$ in Aquifers 1 and 2 can be written as:

$$
\begin{aligned}
& Q_{1}(x, y)=-T_{1} \cdot W_{1}-\frac{\beta}{\left(\alpha_{1}+\alpha_{2}+\alpha_{c}\right)} \cdot \frac{x}{x^{2}+y^{2}} \\
& Q_{2}(x, y)=-T_{2} \cdot W_{2}+\frac{\beta}{\left(\alpha_{1}+\alpha_{2}+\alpha_{c}\right)} \cdot \frac{x}{x^{2}+y^{2}}
\end{aligned}
$$

The $\alpha_{i}$ are aquifer parameters representing the flow path length divided by transmissivity of each part $i$ of the geometry, $\beta$ is a description of the net head loss across the system, $W$ is the head gradient in the $\mathrm{x}$-direction. See Table 1 for further explanation of symbols.

TABLE 1. LIST OF SYMBOLS

\begin{tabular}{|cll|}
\hline Symbol & \multicolumn{1}{c|}{ Name } & Units \\
\hline $\mathrm{B}$ & x-boundary of aquifer & $\mathrm{m}$ \\
$\mathrm{h}$ & hydraulic head & $\mathrm{m}$ \\
$\mathrm{K}$ & hydraulic conductivity & $\mathrm{m} / \mathrm{sec}$ \\
$\mathrm{Q}$ & specific discharge & $\mathrm{m} / \mathrm{sec}$ \\
$\mathrm{r}$ & radial coordinate & $\mathrm{m}$ \\
$\mathrm{T}$ & transmissivity & $\mathrm{m}^{2} / \mathrm{sec}$ \\
$\mathrm{x}, \mathrm{z}$ & cartesian coordinates & $\mathrm{m}$ \\
$\mathrm{z}$ & elevation of top aquifer & $\mathrm{m}$ \\
$\mathrm{W}$ & horizontal head gradient & \\
$\Delta \mathrm{h}_{\mathrm{z}}$ & vertical head difference & $\mathrm{m}$ \\
\hline Subscripts & & \\
\hline $\mathrm{i}$ & Meaning & \\
$\mathrm{c}$ & ith aquifer & \\
$\mathrm{x}$ & chimney & \\
$\mathrm{z}$ & in the horizontal direction & \\
\hline
\end{tabular}




$$
\begin{gathered}
\alpha_{1}=\frac{\ln \left(\frac{B}{r_{c}}\right)}{2 \pi T_{1}} \quad \alpha_{2}=\frac{\ln \left(\frac{B}{r_{c}}\right)}{2 \pi T_{2}} \quad \alpha_{c}=\frac{z_{1}-z_{2}}{K_{c} \pi r_{c}^{2}} \\
\beta=2 r_{c}\left(W_{1}-W_{2}\right)+\Delta h_{z}
\end{gathered}
$$

where $\Delta h_{z}$ is the vertical head difference (preshot) between the aquifers. Directly downgradient, eqs. (1) and (2) describe the total flux in the system (y-component of flux is ()).

The second term in eqs. (1) and (2) represents the contribution to the total flux from groundwater passing through the chimney $\left(\mathrm{Q}_{\mathrm{c}}\right)$. The ratio of this term to the total flux $\mathrm{Q}_{\mathrm{i}}$ in the $i$ th aquifer gives the fractional concentration of "chimney water" in that aquifer at any point downgradient from the chimney. Note that these formulas give meaningful (non-negative) fractions only when the point $(x, y)$ lies downgradient from the chimney, and are undefined at $(0,0)$. The chimney contribution in each aquifer can then be expressed as:

$$
\begin{aligned}
& \frac{\mathrm{Q}_{\mathrm{c}}}{\mathrm{Q}_{1}}=\frac{\beta \mathrm{x}}{4 \pi \mathrm{BT} \mathrm{T}_{1} \mathrm{~W}_{1}\left(\alpha_{\mathrm{c}}+\alpha_{1}+\alpha_{2}\right)\left(\mathrm{x}^{2}+\mathrm{y}^{2}\right)-\beta \mathrm{x}} \\
& \frac{\mathrm{Q}_{\mathrm{c}}}{\mathrm{Q}_{2}}=\frac{\beta \mathrm{x}}{4 \pi \mathrm{BT}_{2} \mathrm{~W}_{2}\left(\alpha_{\mathrm{c}}+\alpha_{1}+\alpha_{2}\right)\left(\mathrm{x}^{2}+\mathrm{y}^{2}\right)-\beta \mathrm{x}}
\end{aligned}
$$

\section{PROCEDURE}

Estimates or constraints are sought on the anticipated time of arrival and the concentration of radionuclides at the site of a proposed downgradient borehole. Because of the lack of hydrologic information at the site, a variety of migration scenarios can be envisioned. The most influential hydrologic unknowns at the Bullion site are the direction of vertical hydraulic gradients and the permeability of the hydrostratigraphic units.

In applying the analytic solutions described above, the Bullion site will be assumed to have two principal "aquifers"; one of low permeability in the zeolitized tuffs (Aquifer 1) and the other of high permeability in the rhyolite flows (Aquifer 2). These aquifers are presumed to be in hydrologic communication via the collapse chimney (i.e., chimney has relatively high vertical permeability).

Two basic scenarios are identified here depending on the direction of vertical gradient. These are the "downward-transport" (Figure 8) and "upward-transport" (Figure 9) scenarios, both assuming low conductivity in the zeolitized tuffs. The unlikely combination of high conductivity in the zeolitized tuffs with downward gradients is included as a "worst-case." The 
Downgradient Well

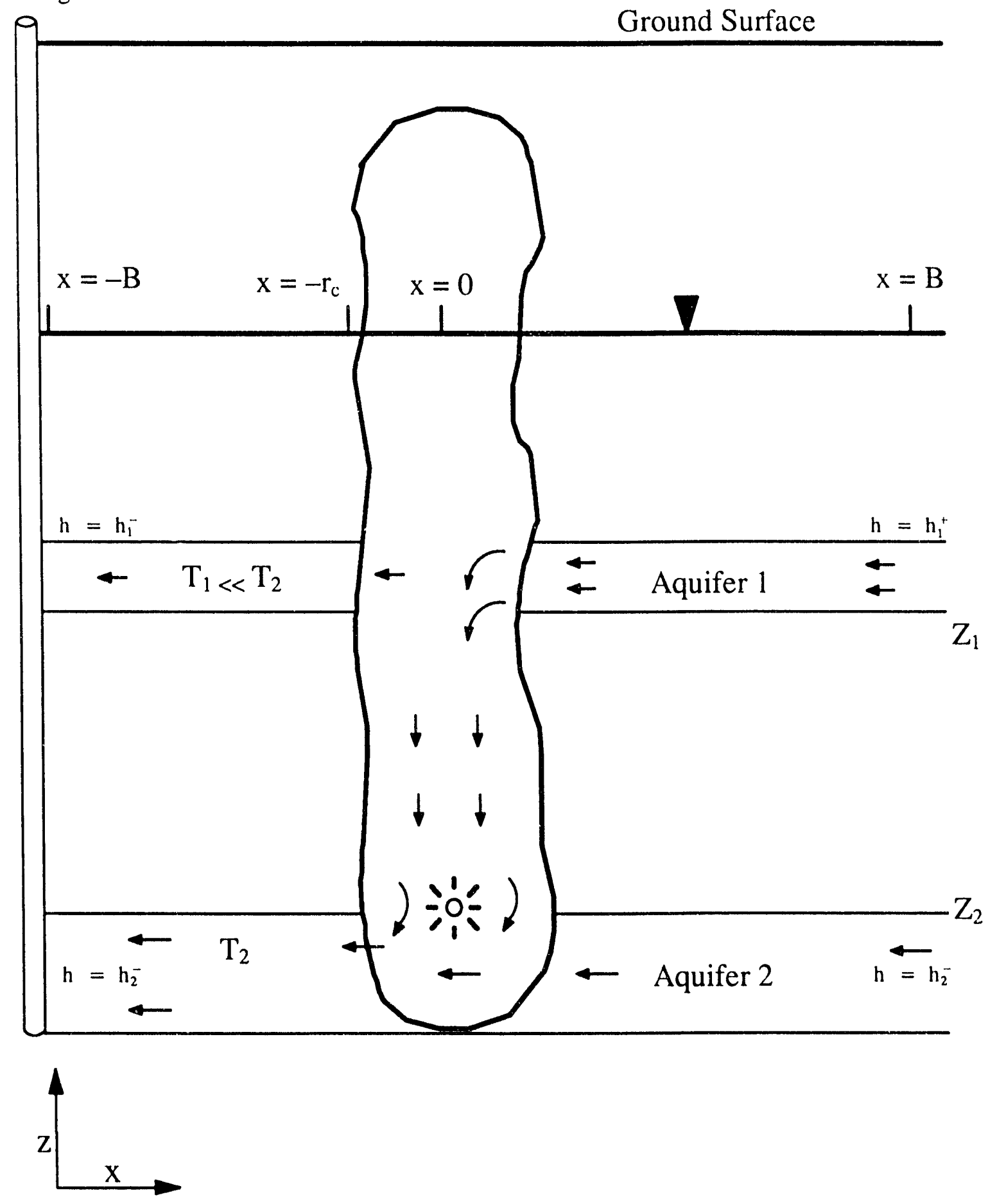

Figure 8. Downward-Transport Scenario for Groundwater Movement and Radionuclide Migration at Bullion. 
Downgradient Well

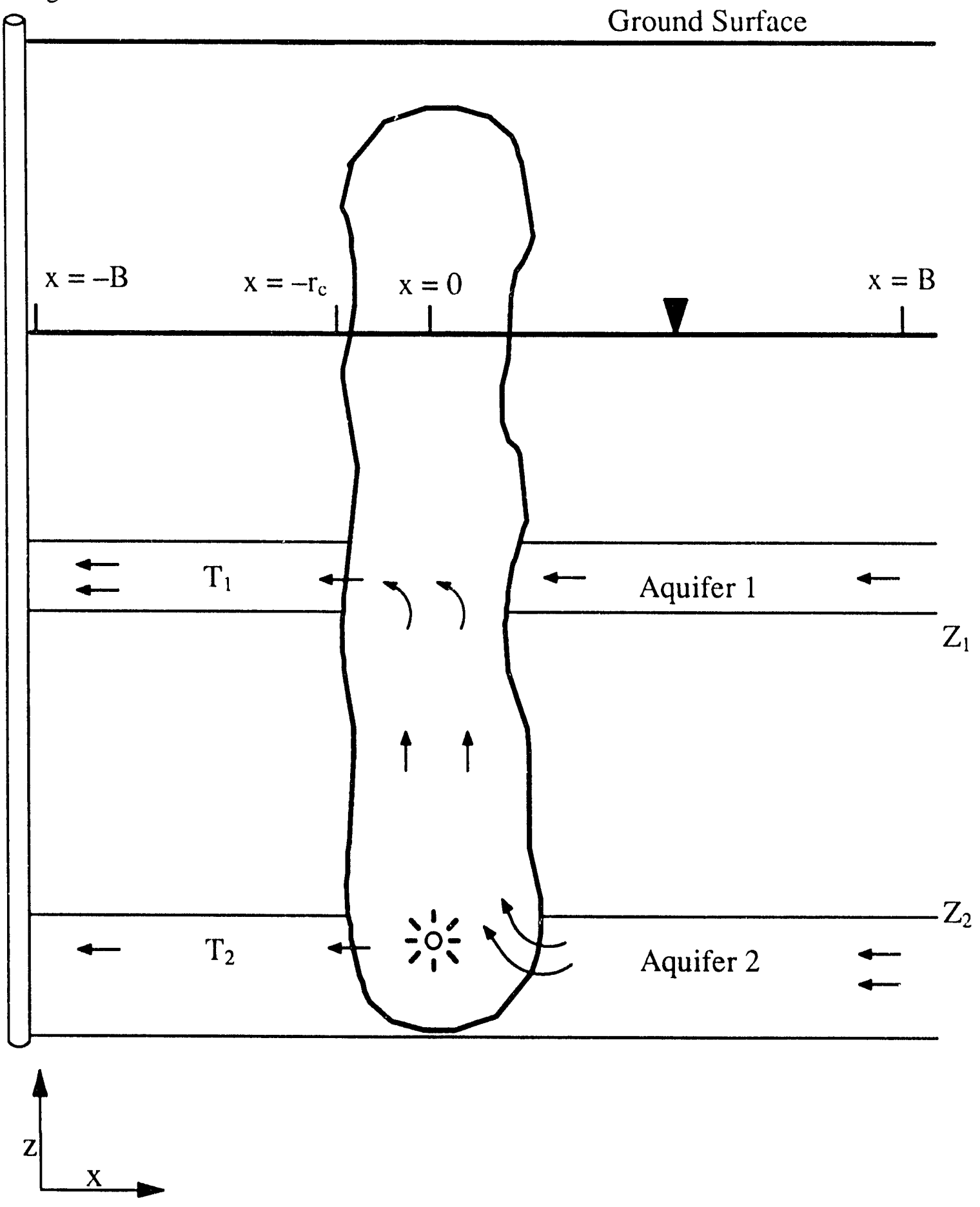

Figure 9. Upward-Transport Scenario for Groundwater Movement and Radionuclide Migration at Bullion. 
case where Aquifers 1 and 2 have similar high conductivity with an upward gradient is essentially identical to the Cheshire case (see Validation section), and is not considered separately for Bullion. The rhyolite flows are likely to be highly conductive and are assumed so in each of the scenarios below.

Given the available information discussed above, appropriate parameter values were selected for each scenario (Table 2). For the aquifer receiving the discharge from the chimney, the chimney contribution, total flux, and contaminant velocity $\mathrm{V}_{\text {pore }}$ were computed for each scenario (Table 3). In addition, computations were carried out for the Cheshire site, where downgradient observations have been made of radionuclide migration.

To compute a value for travel time, the reciproca of pore velocity must be integrated over the path taken by the dissolved species. The particle or pore velocity $V_{\text {pore }}$ is equal to the flux $\mathrm{Q}$ in the aquifer divided by the cross-sectional area (B, assuming a unit width) and the porosity. This integral is difficult to compute and in this study, a constant aquifer flux value equal to that calculated at the well will be assumed. This will give a minimum estimate of the travel time since actual velocity decreases away from the well. The proposed observation well is assumed to be located immediately downgradient from the chimney $(y=0)$ at a distance $x=B$ (see Table 2). Along this path, the chimney contribution to aquifer flux varies as $\frac{1}{x}$ (see eq̣s. 1 and 2). Aquifer

TABLE 2. INPUTS: PARAMETER VALUES USED IN FLUX COMPUTATIONS. CHIMNEY RADIUS $r_{c}$ IS APPROXIMATE.

\begin{tabular}{|c|c|c|c|c|c|}
\hline & & \multicolumn{3}{|c|}{ Bullion } & \multirow{2}{*}{ Units } \\
\cline { 4 - 6 } Parameter & Cheshire & Downward & Upward & Worst & $\mathrm{m}^{2} / \mathrm{sec}$ \\
\hline $\mathrm{T}_{1}$ & $2.33 \times 10^{-4}$ & $1.15 \times 10^{-6}$ & $1.15 \times 10^{-6}$ & $2.33 \times 10^{-4}$ & $\mathrm{~m}^{2} / \mathrm{sec}$ \\
$\mathrm{T}_{2}$ & $2.33 \times 10^{-4}$ & $2.33 \times 10^{-4}$ & $2.33 \times 10^{-4}$ & $2.33 \times 10^{-4}$ & $\mathrm{~m} / \mathrm{sec}$ \\
$\mathrm{K}_{\mathrm{c}}$ & $4.66 \times 10^{-6}$ & $1.0 \times 10^{-7}$ & $1.0 \times 10^{-7}$ & $4.66 \times 10^{-6}$ & $\mathrm{~m}$ \\
$\mathrm{r}_{\mathrm{c}}$ & 100 & 70 & 70 & 70 & $\mathrm{~m}$ \\
$\mathrm{~B}$ & 305 & 300 & 300 & 300 & $\mathrm{~m}$ \\
$\mathrm{z}_{1}$ & 1250 & 1350 & 1350 & 1350 & $\mathrm{~m}$ \\
$\mathrm{z}_{2}$ & 900 & 1230 & 1230 & 1230 & 0.02 \\
$\mathrm{~W}_{1}, \mathrm{~W}_{2}$ & 0.02 & 0.02 & 0.02 & 0.02 & \\
$\Delta \mathrm{h}_{\mathrm{z}}$ & -0.02 & 0.02 & -0.02 & \\
\hline
\end{tabular}


TABLE 3. RESULTS: CIIMNEY CONTRIBUTION AND TOTAL FLUX FOR BULLION SCENARIOS.

\begin{tabular}{|c|c|c|c|c|c|}
\hline \multirow[b]{2}{*}{ Parameter } & \multirow[b]{2}{*}{ Cheshire } & \multicolumn{3}{|c|}{ Bullion } & \multirow[b]{2}{*}{ Units } \\
\hline & & Downward & Upward & Worst & \\
\hline$\frac{Q_{c}}{Q_{i}}$ & 0.0103 & 0.00099 & 0.165 & $(0.070$ & \\
\hline$Q_{i}$ & $5.19 \times 10^{-6}$ & $+.60 \times 10^{-6}$ & $2.75 \times 10^{-8}$ & $4.95 \times 10^{-6}$ & $\mathrm{~m}^{3} / \mathrm{sec}$ \\
\hline$V_{\text {pore }}$ & $1.04 \times 10^{-6}$ & $9.20 \times 10^{-7}$ & $5.50 \times 10^{-9}$ & $9.90 \times 10^{-7}$ & $\mathrm{~m} / \mathrm{sec}$ \\
\hline$t_{\text {arrival }}$ & 9.14 & 10.33 & 1,728 & 9.60 & $y r$ \\
\hline
\end{tabular}

$\mathrm{i}=2$ for downward-transport

$i=1$ for Cheshire and upward-transport case

$\mathrm{V}_{\text {pore }}$ computed assuming 50-m-thick aquifer and effective porosity of 10 percent

$t_{\text {arrival }}$ is time of first arrival at downgradient hole.

flux varies by a factor of four between the chimney and observation well and, therefore, the error in estimated travel time introduced by the assumption of constant velocity will be less than or equal to 25 percent.

Predicted arrival times at the downgradient well are summarized for each site at the bottom of Table 3. Scenarios in which radionuclides move primarily in the rhyolitic flows result in predicted arrival times of about 10 years to the downgradient well. Arrival times are two orders of magnitude larger for flow in the tuffs, reflecting their lower permeability.

\section{Validation}

The Cheshire site offers a unique opportunity to test this approach. At that site, radionuclides were found to have migrated from the chimney into an upper aquifer. The point of highest concentration had moved beyond a downgradient observation well, a distance of 305 $\mathrm{m}$ in 11 years, implying a minimum velocity of $8.8 \times 10^{-7} \frac{\mathrm{m}}{\mathrm{scc}}$. A probable maximum velocity is $1.2 \times 10^{-6} \frac{\mathrm{m}}{\mathrm{scc}}$, assuming first arrival of contaminants to have taken place at eight years. Application of eq. (1), given the parameters listed in Table 2, predicts a flux at the downgradient well of $5.19 \times 10^{-6} \frac{\mathrm{m}^{3}}{\mathrm{scc}}$. Aquifers at Cheshire (actually fracture zones) were reported to be approximately $50 \mathrm{~m}$ thick. This would yield a groundwater velocity of $1.04 \times 10^{-6} \frac{\mathrm{m}}{\mathrm{scc}}$ (Table 3), similar to the velocity implied by downgradient observations at Cheshire. This is encouraging, even with the greatly simplified depiction used here and the average rock properties discussed above, computed values for velocity and travel time at Cheshire are 
consistent with available field observations. Predictions of concentration did not fare as well, possibly a result of the assumption of complete mixing in these solutions, the ignored effects of thermal input (Brikowski, 1989), or to overestimation of $\frac{T_{1}}{T_{2}}$. Initial concentrations of tritium in the Cheshire cavity were $2.0 \frac{\mu \mathrm{Ci}}{\mathrm{ml}} ; 11$ years after the Cheshire event tritium concentrations of (). 6 $\frac{\mu \mathrm{Ci}}{\mathrm{ml}}$ (decay corrected) were found in the downgradient well, a dilution of 30 percent (Erikson, 1990). Computations using eq. (3) predict a one percent dilution factor at the downgradient well, an order of magnitude lower than observed (Table 3).

\section{Predictions}

The most reliable aspect of the results presented in Table 3 are their relative magnitudes. The procedure discussed above attempts to constrain a transient chemical transport process using a description of steady groundwater flow. This is not unreasonable, if groundwater velocities are reduced by an order of magnitude, chemical transport rates are likely to be reduced by a similar amount; however, knowledge of the velocities alone is not enough to produce an accurate prediction of transport rates. Groundwater fluxes for the Bullion "upward-transport" scenario are predicted to be two orders of magnitude lower than at Cheshire (Table 3). Assuming effective porosity does not vary between the two sites, groundwater velocities will also be two orders of magnitude lower, and travel times for conservative species will be increased by the same factor. This prediction is based solely on the anticipated relative effect of reduced groundwater fluxes in the upper aquifer. The implied travel time for radionuclides to arrive at the downgradient well in the "upward-transport" scenario is approximately $2,0(0)$ years.

In the "downward-transport" scenario, travel times to the downgradient well should be similar to those observed at Cheshire (approximately 10 years). Radionuclide concentrations in this case are predicted to be an order of magnitude lower than those observed at Cheshire, because less flux occurs through the chimney. Travel times are similar because conductivity in the rhyolite flows is assumed identical to Cheshire in this scenario. Results for the "worst-case" scenario predict similar fluxes and travel times but higher concentrations since high conductivity in the upper aquifer allows more water to move through the chimney.

The most probable scenario is a combination of these results. Radionuclides injected into the rhyolite flow migrate horizontally as in the "downward transport" case, while those in the chimney above the rhyolite flows migrate horizontally as in the "upward-transport" case. In effect, the tuff-walled portion of the chimney will act as a dead-end storage reservoir, its low-permeability sides inhibiting horizontal and vertical flow. Assuming a radionuclide distribution in the chimney similar to that observed at Faultless, approximately 25 percent of the 
total tritium produced in the test would be found in the rhyolites, and would move rapidily to the downgradient well in this combined scenario.

\section{Uncertainty}

The hydraulic parameters at the Bullion site are particularly uncertain. The equations developed above can also be used to show the variation of chimney contribution or total flux with respect to any parameter. As noted above, the most influential parameters at this site are the transmissivity of upper units, magnitude of vertical gradients, and conductivity of the chimney.

For the upward-transport scenario, flux in Aquifer 1 and, therefore, travel time, is primarily controlled by $T_{1}$ (or alternatively the magnitude of the latteral gradient, Figure 10). This is not surprising since the bulk of the travel path for radionuclides from the chimney would be in Aquifer 1. The slope of 1 for the $T_{1}$ line in Figure 10 indicates that order of magnitude errors in estimates of $T_{1}$ will lead to similar errors in flux and travel-time estimates. Errors in other factors will have little influence, except in the case of unusually large upward head gradients $\left(\delta_{\%}\right)$. Chimney contribution or dilution factor is more sensitive to other factors (Figure 11). High concentrations are found downgradient only when conductivity of the chimney and upper aquifer are of the same order of magnitude or when vertical gradients are extreme.

In the downward-transport scenario, flux and travel-time estimates will similarly be sensitive to $\mathrm{T}_{2}$ (not shown) and otherwise are relatively insensitive to parameters other than the cavity radius and extremes in vertical gradient (Figure 12). The chimney and upper aquifer are presumed to have equal or smaller conductivity than the lower aquifer and, therefore, have little effect on fluxes there. In the case of chimney contribution, sensitivity similar to the upward-transport scenario is seen (Figure 13). Changes in $T_{1}$ now produce a proportional increase in contribution since increased flux in the upper aquifer encourages flushing of the chimney contents downward.

\section{CONCLUSIONS}

The expected time required for non-sorbing radionuclides to travel from the Bullion cavity to a downgradient well $300 \mathrm{~m}$ away from ground zero is on the order of 10 years, assuming injection into the rhyolite flows. Approximately three-quarters of the tritium at the site is expected to remain in the zeolitized tuff-walled portion of the chimney indefinitely. If strong upward gradients are present, radionuclides may require up to 2,000 years to arrive at the downgradient well.

The predictions presented here are approximate, but help to constrain the expected travel time, and provide an indication of the possible errors related to parameter uncertainty. Further 

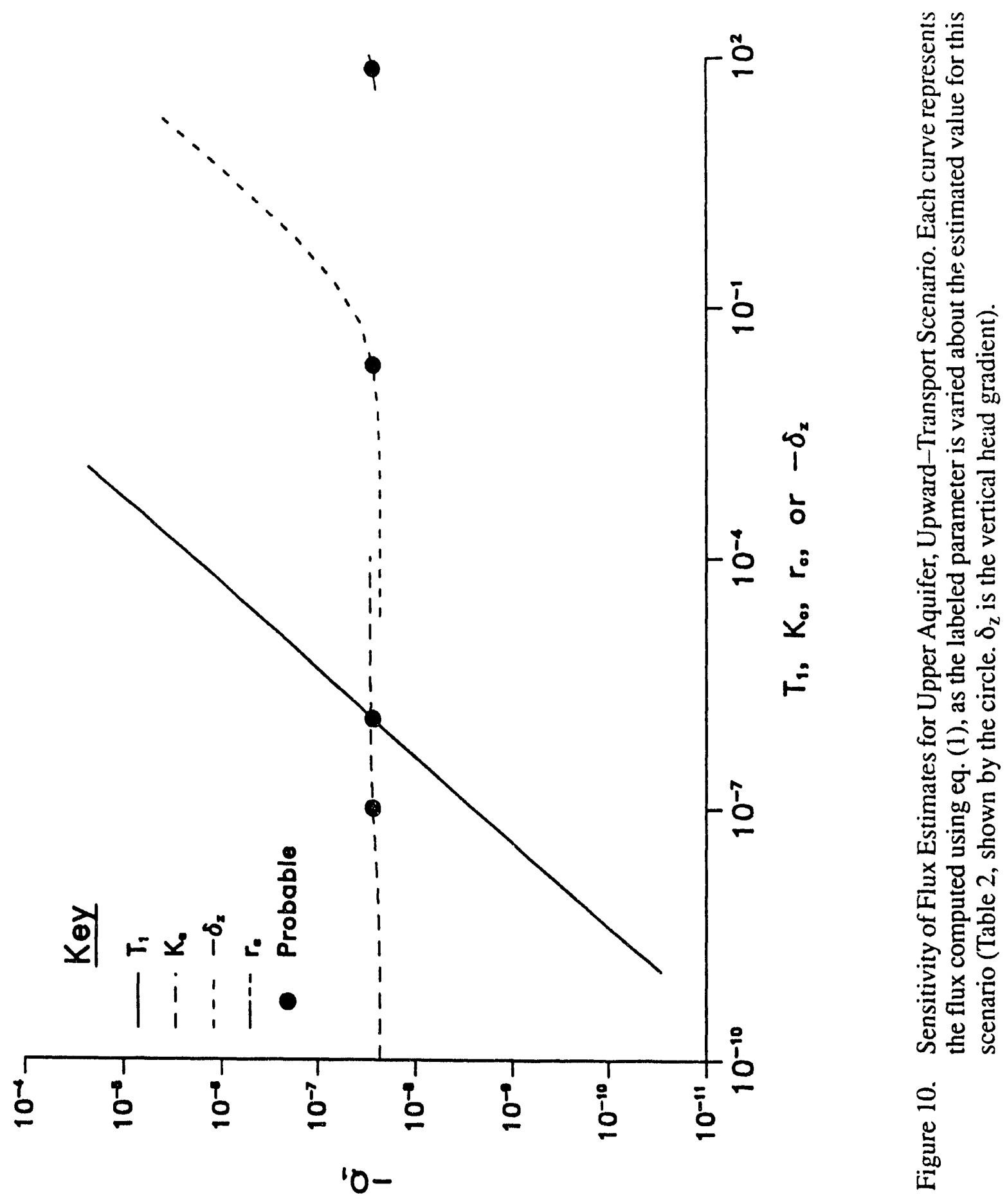

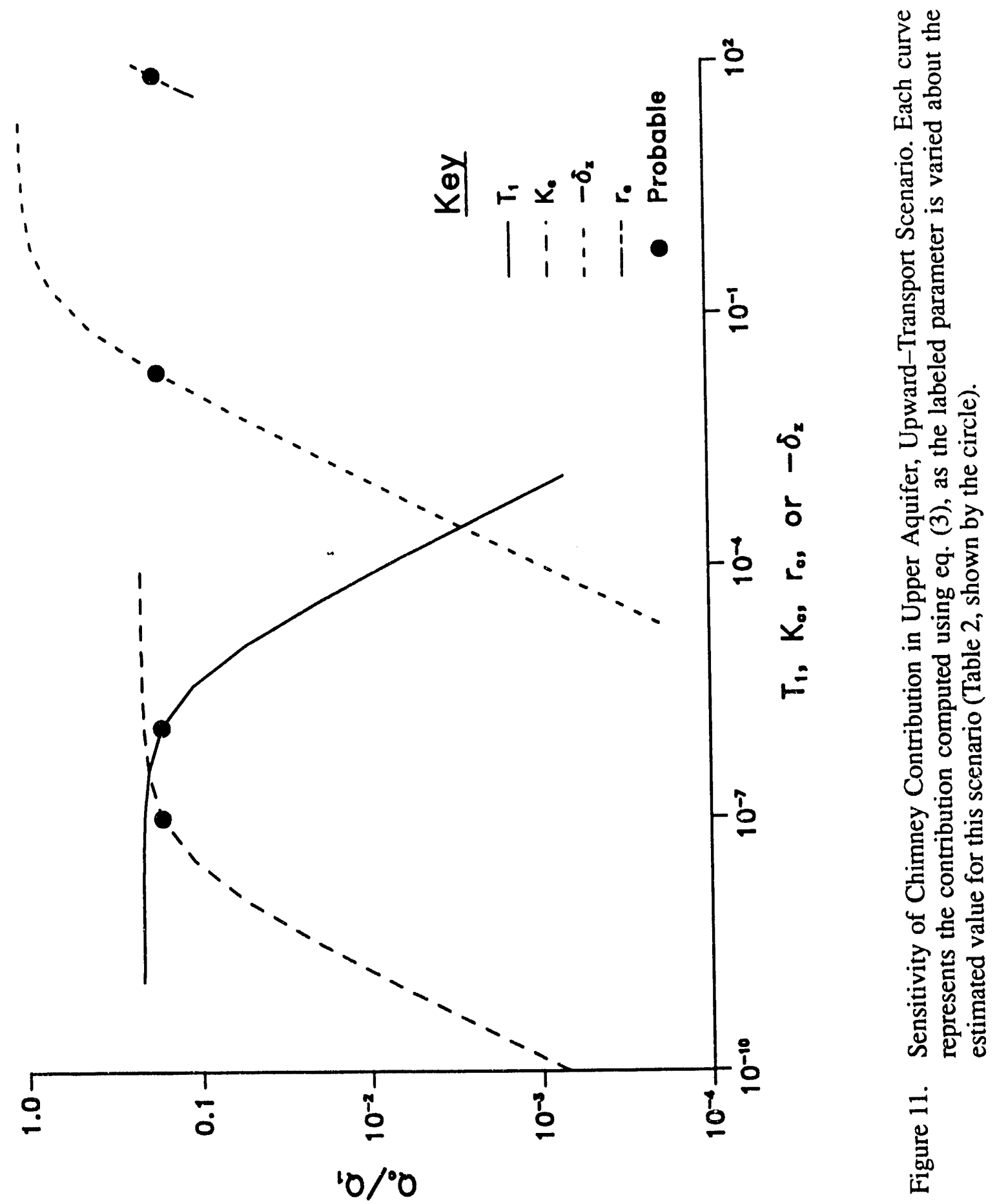

22 


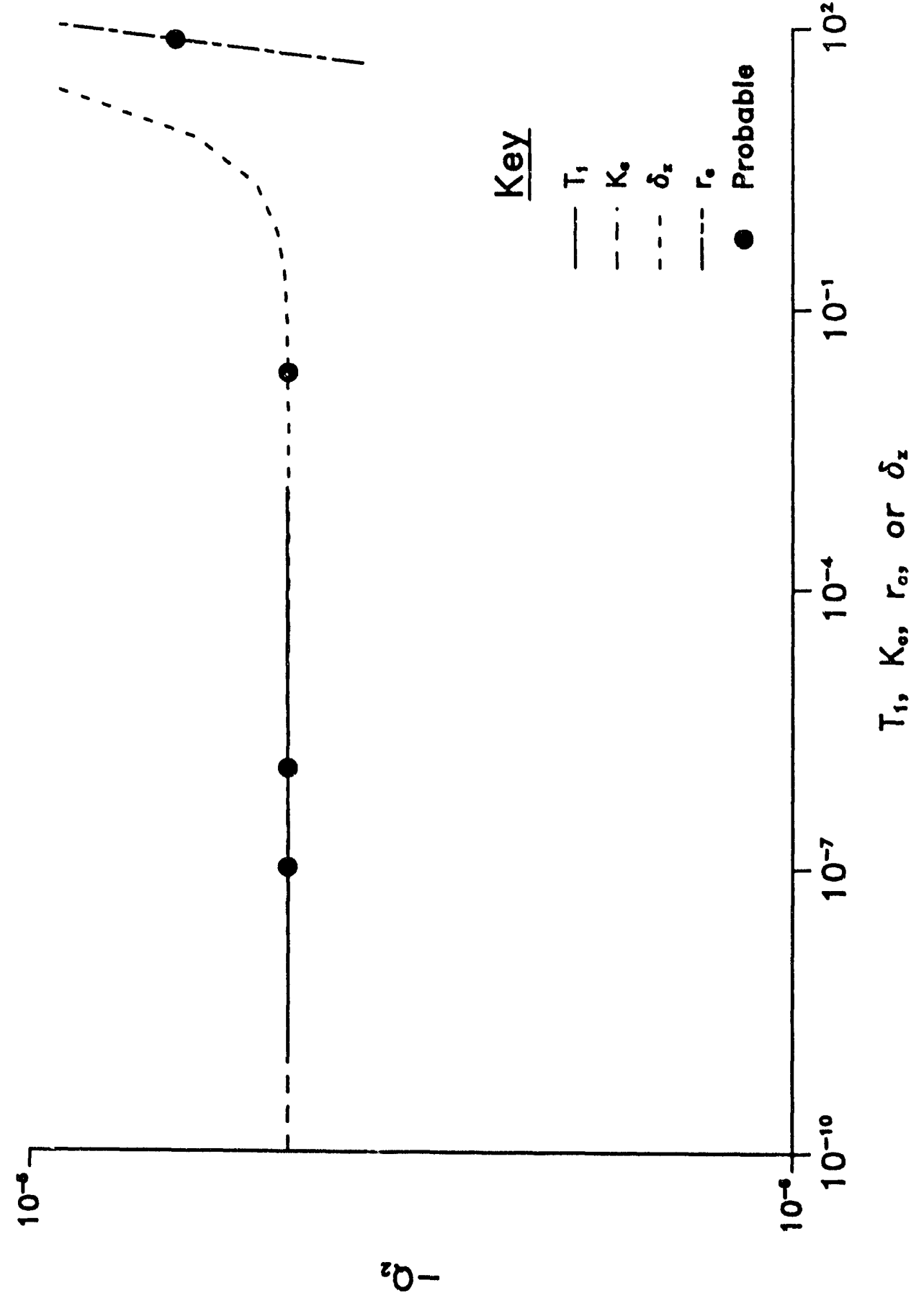

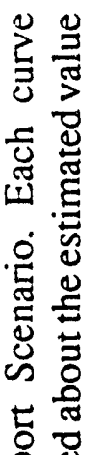

ह

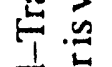

은

3

喝

过

这

훙

<完

证

임

홍

的

\%

है क

敦

空

崌药

可总。

出

它

跑

突

这递

ํㅗㄹ 


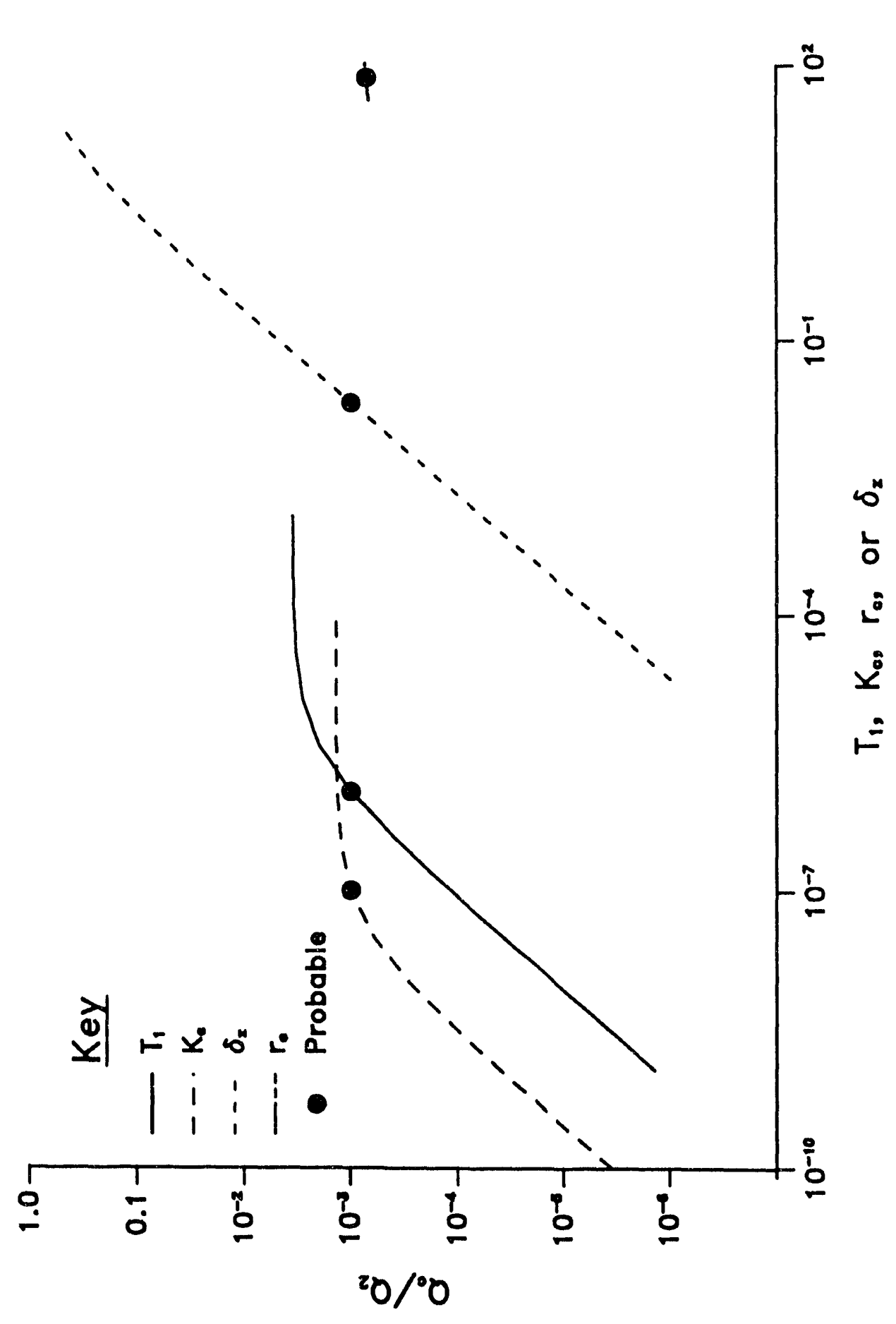

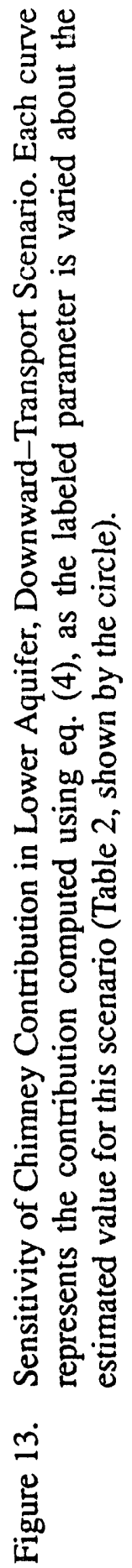


predictions should include the effects of infilling of the cavity and thermal input from the test. Consideration of these processes will require numerical modeling. The uncertainty estimates presented here can be applied to such modeling results as well and, in fact, may be more useful than the travel-time predictions included above.

A final caveat is in order. Hydrologic predictions are only as good as the data upon which they are based. Since minimal hydrologic data are available at the Bullion site, the accuracy of the predictions made here must be regarded accordingly. If reliable predictions of radionuclide migration are desired in the future, there must be a procedure for obtaining hydrologic data (the vertical distribution of head and hydraulic conductivity) at each site before testing takes place. Otherwise, it will be impossible to know in advance if a site is worth monitoring for radionuclide migration via groundwater, and downgradient wells may yield only uncontaminated samples. Unfortunately, failure to encounter radionuclides in the downgradient well will not necessarily constitute proof that transport is negligible at Bullion or any site. The conductivity in the saturated zone of most of the NTS lies in fractures, which may have limited connectivity in some directions. Radionuclides could move great distances along one fracture set, and be undetectable in a neighboring set. While this seems unlikely at the Bullion site, a single downgradient well will not conclusively demonstrate that transport is negligible even if no radionuclides are encountered.

\section{REFERENCES}

Blankennagel, R.K. and J.E. Weir, 1973. Geohydrology of the Eastern Part of Pahute Mesa, Nevada Test Site, Nye County, Nevada. U.S. Geological Survey, U.S. Geological Survey Prof. Paper 712-B, Washington, D.C.

Borg, I.Y., R. Stone, H.B. Levy and L.D. Ramspott. 1976. Information Pertinent to the Migration of Radionuclides in Ground Water at the Nevada Test Site, Part 1: Review and Analysis of Existing Information. Lawrence Livermore National Laboratory, UCRL-52078 Pt. 1, Livermore, California.

Brikowski, T.H., 1989. Hydrologic Phenomena Related to Underground Nuclear Tests in the Saturated Zone: Man-made Hydrothermal Systems?. EOS, 70, 1100.

Brikowski, T.H., 1991a. The Hydrology of Underground Nuclear Tests: The Effect of Collapse-Chimney Formation. Desert Research Institute, Publication \#45090, 20 p., Las Vegas, Nevada.

Brikowski, T.H., 1991b. The Hydrology of Underground Nuclear Tests: Constraints on Potential Radionuclide Migration from Analytic Models. Paper presented at Sixth Symposium on Containment of Underground Nuclear Explosions, Reno, Nevada, Sept. 24-27, Abstract: Conf-9109114-ABS (Proceedings volume in press). 
Brikowski, T.H., 1992a. Flow Between Aquifers Through Filled Cylindrical Conduits: Analytic Solution and Application to Underground Nuclear Testing Sites. J. Hydrol., 19 p. (in review).

Brikowski, T.H., 1992b. Estimating Movement of Groundwater from a Pond or Large-Radius Conduit. Ground Water, 17 (submitted).

Drellack, S.J., 1987. Geology of Drill Hole UE-20N\#1. Fenix \& Scisson, Memorandum (LANL/F\&S/NTS), June 6, Las Vegas, Nevada.

Eriksun, S.J., 1991. Report of the Drilling and Radionuclide Migration Investigations at UE-20n\#1, Pahute Mesa, Nevada Test Site, 1987. Desert Research Institute, Publication \#45081, 118 p., Reno, Nevada.

Fenske, P.R., 1969. Prediction of Radionuclide Migration in Groundwater, in Technical Discussion of Off-site Safety Programs for Underground Nuclear Detonations. USAEC Isotopes Inc., Chp. 7, NVO-4() Rev. 2, pp. 69-82, Palo Alto, California.

Garber, MS., 1971. A Method for Estimating Effective Porosity in a Rubble Chimney Formed by an Underground Nuclear Explosion. U.S. Geological Survey Prof. Paper 75()-C, Denver, Colorado.

Glasstone and Dolan, 1977. The Effects of Nuclear Weapons. U.S. Department of Defense, 3rd ed., 653 p., Washington, D.C.

Lawrence Livermore National Laboratory, 1990. U-20bd Site Characteristics Report. Internal Report CP 89-167, Livermore, California.

B. McKinnis, 1990. Personal Communication.

Thordarson, W., 1985. Hydrogeologic Monitoring at the Faultless Site, Nye County, Nevada. U.S. Geological Survey, Open-File Rept. OFR-84-580, Denver, Colorado.

Thordarson, W., 1987. Hydrogeology of the Faultless Site, Nye County, Nevada. U.S. Geological Survey, Open-File Rept. OFR-86-4342, Denver, Colorado. 
DATE FILMED $12 / 17 / 92$ 
